\title{
Effects of corticosteroids on bronchodilator action in chronic obstructive lung disease
}

\author{
Johan B Wempe, Dirkje S Postma, Nanke Breederveld, Erwin Kort,
} Thomas W van der Mark, Gerard H Koëter

\begin{abstract}
Background Short term treatment with corticosteroids does not usually reduce airflow limitation and airway responsiveness in patients with chronic obstructive lung disease. We investigated whether corticosteroids modulate the effects of inhaled salbutamol and ipratropium bromide.

Methods Ten non-allergic subjects with stable disease were investigated; eight completed the randomised, double blind, three period cross over study. Treatment regimens consisted of $1.6 \mathrm{mg}$ inhaled budesonide a day for three weeks, $40 \mathrm{mg}$ oral prednisone a day for eight days, and placebo. After each period cumulative doubling doses of salbutamol, ipratropium, a combination of salbutamol and ipratropium, and placebo were administered on separate days until a plateau in $\mathrm{FEV}_{1}$ was reached. A histamine challenge was then performed.
\end{abstract}

Results At the end of placebo treatment mean FEV $_{1}$ was $55.5 \%$ predicted after inhaled placebo, $67.9 \%$ predicted after salbutamol and $64.0 \%$ predicted after ipratropium. Compared with the results after the placebo period the $F E V_{1}$ with salbutamol increased by $0.7 \%$ predicted after treatment with budesonide and by $0.7 \%$ predicted after treatment with prednisone; the $\mathrm{FEV}_{1}$ with ipratropium increased by $0.7 \%$ predicted after budesonide and by $4.8 \%$ predicted after prednisone; none of these changes was significant. After placebo treatment the geometric mean $\mathbf{P C}_{20}$ was $0.55 \mathrm{mg} / \mathrm{ml}$ after placebo, $1.71 \mathrm{mg} / \mathrm{ml}$ after salbutamol and $0.97 \mathrm{mg} / \mathrm{ml}$ after ipratropium. Compared with the placebo period the $\mathbf{P C}_{20}$ with salbutamol was increased by 0.86 doubling concentrations after treatment with budesonide, and by 0.67 doubling concentrations after prednisone; the $\mathbf{P C}_{20}$ with ipratropium increased by 0.03 and 0.34 doubling concentrations after budesonide and after prednisone respectively compared with placebo; none of these changes was significant.

Conclusions In non-allergic subjects with chronic obstructive lung disease short term treatment with high doses of inhaled or oral corticosteroids does not modify the bronchodilator response to salbutamol or ipratropium or the protection provided by either drug against histamine. Salbutamol produces greater protection from histamine induced bronchoconstriction than ipratropium.

Corticosteroids have been shown to improve symptoms, lung function, and airway responsiveness in subjects with asthma. ${ }^{1-3}$ The effects of oral and inhaled corticosteroids in patients with chronic obstructive lung disease are less clear, ${ }^{4-10}$ perhaps partly because of heterogeneity among these patients. Previous studies of corticosteroid treatment in patients with chronic obstructive lung disease have looked mainly at changes in airflow limitation and airway responsiveness. In some studies corticosteroids produced no benefit ${ }^{79}$ whereas in others benefit was seen in patients with atopy and eosinophilia ${ }^{46}$ or reversible airflow limitation. ${ }^{5}$ It has been suggested that corticosteroids, apart from an effect on lung function, may influence the effects of a bronchodilator as they potentiate the response to $\beta$ agonists in asthmatic ${ }^{1011}$ and normal subjects. ${ }^{12}$ The combination of a corticosteroid and an anticholinergic agent was more effective in subjects with asthma than either drug alone, but this was not the case in patients with chronic bronchitis. ${ }^{13}$ The aim of the present study was to investigate whether the effects of $\beta$ adrenergic and anticholinergic bronchodilators are modified by treatment with corticosteroids in non-allergic subjects with stable chronic obstructive lung disease. The effects of cumulative doubling doses of salbutamol and ipratropium on airflow limitation and airway responsiveness were studied after treatment with high dose oral and inhaled corticosteroids.

\section{Methods}

PATIENTS

Eight men and two women, aged 49 to 66 years, were examined after giving informed consent. All patients had dyspnoea continuously or on exertion and were current or former smokers. None had a history of attacks of wheezing and dyspnoea consistent with asthma. All were clinically stable with no respiratory infection or exacerbation in the two months before the study. Patients were selected only if they had negative skin test results for common inhaled allergens, normal concentrations of total $\mathrm{IgE}$, a baseline forced expiratory volume in one second $\left(\mathrm{FEV}_{1}\right)$ of $40-80 \%$ of the predicted 
value ( $\%$ predicted), ${ }^{14}$ and a provocation concentration of histamine causing a $20 \%$ fall in $\mathrm{FEV}_{1}\left(\mathrm{PC}_{20}\right)$ of less than $8 \mathrm{mg} / \mathrm{ml}$. The study was approved by the hospital medical ethics committee.

\section{PROTOCOL}

When subjects came to the lung function laboratory for assessment they had taken no inhaled corticosteroid for six weeks and no bronchodilator except for $\beta$ agonists for two weeks. Spirometry and a histamine challenge test were performed. Subjects then entered a double blind, randomised, cross over study consisting of three treatment periods of three weeks, each of which was followed by four study days. During each treatment period patients received four puffs twice daily by metered dose inhaler with a spacing device (Spacer, Astra-Draco, Lund, Sweden) for three weeks and four tablets twice daily for the last eight days. The treatment regimens were (a) inhaled budesonide ( $1.6 \mathrm{mg}$ daily) and placebo tablets; $(b)$ inhaled placebo and prednisone tablets (40 mg daily); and (c) inhaled placebo and placebo tablets. The study treatment was continued during the four study days. Inhaler technique was checked on every visit. Inhaled salbutamol was allowed if required during the study except in the 12 hours before the start of the measurements.

On the four study days after each treatment period the airway response to cumulative doubling doses of bronchodilators was measured. Bronchodilator solutions contained ipratropium, salbutamol, a combination of the two drugs, or saline, and were administered by nebuliser in a double blind, randomised and cross over design.

\section{SPIROMETRY AND HISTAMINE RESPONSIVENESS}

$\mathrm{FEV}_{1}$ was measured with a water sealed spirometer (Lode BV, Groningen, Netherlands), the best of three attempts being accepted. Bronchial challenge tests were performed by the method described by Cockcroft et al ${ }^{15}$ with a De Vilbiss 646 nebuliser (De Vilbiss, Somerset, United States) with an output of $0.13 \mathrm{ml} / \mathrm{min}$. A $0.9 \%$ phosphate buffered saline solution and doubling histamine diphosphate concentrations from 0.03 to $16 \mathrm{mg} / \mathrm{ml}$ were inhaled for two minutes at five minute intervals until the $\mathrm{FEV}_{1}$ had fallen by $20 \%$ from the value obtained after inhaling saline. The provocative concentration of histamine causing a $20 \%$ fall in $\mathrm{FEV}_{1}\left(\mathrm{PC}_{20}\right)$ was calculated by interpolation of the last two points of the $\log$ dose-response curve. Values above $8 \mathrm{mg} / \mathrm{ml}$ were considered to be normal. If the $\mathrm{PC}_{20}$ was greater than $16 \mathrm{mg} / \mathrm{ml}$ an extrapolation was performed from the last two points of the curve. If the $P_{20}$ was greater than $32 \mathrm{mg} / \mathrm{ml} \mathrm{a}$ $\mathrm{PC}_{20}$ value of $64 \mathrm{mg} / \mathrm{ml}$ was assigned.

\section{BRONCHODILATOR ASSESSMENT}

Patients were studied at 8 to 8.30 am after 15 minutes' rest, provided that the baseline FEV on days $2-4$ was within $10 \%$ of the $\mathrm{FEV}_{1}$ on day 1. Solutions for nebulisation were prepared immediately before use from stock solutions of ipratropium bromide $0.25 \mathrm{mg} / \mathrm{ml}$ without preservatives, salbutamol sulphate $5 \mathrm{mg} / \mathrm{ml}$, and a $0.9 \%$ sodium chloride solution. The solutions were isotonic and the $\mathrm{pH}$ was $3 \cdot 5$. Drugs were nebulised by a HICO-Ultrasonic nebuliser type 806E (Hirtz, Cologne, Germany) with an output of $0.6 \mathrm{ml} / \mathrm{min}$ ( $3 \mathrm{ml}$ during five minutes of tidal breathing). Patients wore a noseclip during nebulisation. Nebulised doses were $0.19,0.38,0.75,1.5$, and $3.0 \mathrm{mg}$ ipratropium and $0.94,1.88,3.75,7.5$, and $15.0 \mathrm{mg}$ salbutamol. The combination (ipratropium/ salbutamol) was given in doses of $0.09 / 0.47$, $0 \cdot 19 / 0 \cdot 94,0 \cdot 38 / 1 \cdot 88,0 \cdot 75 / 3 \cdot 75$, and $1 \cdot 5 / 7 \cdot 5 \mathrm{mg}$. Subjects rested one hour after each inhalation before $\mathrm{FEV}_{1}$ was measured again. The experiment was discontinued when $\mathrm{FEV}_{1}$ increased less than 5\% compared with the previous measurement. One hour after the final nebulisation a histamine challenge was performed.

\section{DATA ANALYSIS}

$\mathrm{PC}_{20}$ values were $\log _{2}$ transformed for analysis; change in $\mathrm{PC}_{20}$ was measured in doubling concentrations. FEV 1 was expressed as a percentage of the predicted value ( $\%$ predicted). ${ }^{14}$

Multivariate analysis of variance of repeated measurements was used for initial analysis. Dependent variables were $\mathrm{FEV}_{1}$ and $\mathrm{PC}_{20}$, and explanatory factors were treatment, bronchodilator administered, and two way interactions between treatment and bronchodilator administered. Student's $t$ tests for paired observations were used to compare treatment regimens and bronchodilators when significant treatment and bronchodilator effects emerged. Trends and carry over effects were tested by adding "period" factor and the interaction term "treatment $\times$ period" to the models. These were omitted from the final models when not significant.

The effects of combining the corticosteroids and bronchodilators were assessed in two ways. Firstly, the two way interaction factor of all combinations of corticosteroids and bronchodilators was evaluated by multivariate analysis of variance, the null hypothesis being that the interactive effect is zero-that is, that the observed value for the combination of corticosteroids and bronchodilators is equal to the sum of their separate effects (an additive effect). A positive interactive effect indicates that the effect of the combination was larger than the sum of the separate effects (synergistic), whereas a negative interactive effect implies a smaller effect from the combination than would be expected from the sum of their separate effects (antagonistic). Secondly, we assessed whether the values after combination of corticosteroids and bronchodilator, whatever the nature of their interaction, differed from the values after bronchodilator following the placebo treatment period; values after bronchodilator following the three treatment periods were compared by paired $t$ tests.

Individual responses to corticosteroids and bronchodilators were calculated by multiple linear regression by using models which included dummy variables for budesonide, pred- 
Table 1 Characteristics of subjects on day of selection for study

\begin{tabular}{|c|c|c|c|c|c|c|c|c|c|}
\hline $\begin{array}{l}\text { Patient } \\
\text { No }\end{array}$ & $\begin{array}{l}\text { Age } \\
\text { (years) }\end{array}$ & Sex & $\begin{array}{l}\text { Smoking } \\
\text { status }\end{array}$ & $\begin{array}{l}\text { Eosinophil } \\
\text { count } \\
\left(\times 10^{6} / l\right)\end{array}$ & $F E V_{l}(l)$ & $\begin{array}{l}F E V_{1} \\
(\% \\
\text { predicted) }\end{array}$ & $\begin{array}{l}F E V, \% V C \\
(\%)\end{array}$ & $\begin{array}{l}P C_{20} \\
\text { histamine } \\
(\mathrm{mg} / \mathrm{ml})\end{array}$ & $\begin{array}{l}\text { Maintenance } \\
\text { treatment }\end{array}$ \\
\hline 1 & 59 & $\mathbf{M}$ & Former & 88 & $2 \cdot 90$ & $76 \cdot 3$ & $61 \cdot 7$ & $0 \cdot 71$ & $\begin{array}{l}\text { Inhaled corticosteroids, } \\
\text { ipratropium }\end{array}$ \\
\hline 2 & 64 & $\mathbf{M}$ & Current & 154 & $1 \cdot 75$ & $52 \cdot 0$ & $50 \cdot 0$ & 0.56 & $\begin{array}{l}\text { Inhaled corticosteroids, } \\
\text { ipratropium, } \\
\text { theophylline }\end{array}$ \\
\hline 3 & 49 & $\mathbf{M}$ & Current & 77 & $1 \cdot 80$ & $51 \cdot 6$ & $52 \cdot 9$ & $0 \cdot 23$ & $\begin{array}{l}\text { Inhaled corticosteroids, } \\
\text { ipratropium }\end{array}$ \\
\hline 4 & 62 & $\mathbf{M}$ & Current & 429 & 1.50 & $44 \cdot 5$ & $39 \cdot 0$ & $0 \cdot 14$ & $\begin{array}{l}\text { Inhaled corticosteroids, } \\
\text { ipratropium, } \\
\text { theophylline }\end{array}$ \\
\hline 5 & 57 & $\mathbf{F}$ & Current & 99 & $1 \cdot 45$ & $58 \cdot 2$ & $58 \cdot 0$ & $0 \cdot 75$ & $\begin{array}{l}\text { Inhaled corticosteroids, } \\
\text { ipratropium }\end{array}$ \\
\hline 6 & 58 & $\mathbf{M}$ & Former & 33 & $2 \cdot 00$ & $57 \cdot 5$ & $56 \cdot 3$ & $1 \cdot 38$ & $\begin{array}{l}\text { Inhaled corticosteroids, } \\
\text { ipratropium }\end{array}$ \\
\hline 7 & 66 & $\mathbf{M}$ & Current & 33 & $1 \cdot 85$ & $70 \cdot 9$ & $40 \cdot 2$ & $0 \cdot 30$ & $\begin{array}{l}\text { Theophylline, } \\
\text { promethazine }\end{array}$ \\
\hline 8 & 55 & $\mathbf{M}$ & Former & $<11$ & $1 \cdot 85$ & $53 \cdot 2$ & $52 \cdot 1$ & 0.42 & Promethazine \\
\hline 9 & 52 & $\mathbf{M}$ & Current & $<11$ & 1.50 & $45 \cdot 3$ & $46 \cdot 3$ & $0 \cdot 38$ & $\begin{array}{l}\text { Inhaled corticosteroids, } \\
\text { ipratropium }\end{array}$ \\
\hline 10 & 49 & $\mathbf{F}$ & Former & 22 & $2 \cdot 00$ & $79 \cdot 1$ & $72 \cdot 1$ & $2 \cdot 33$ & Salbutamol \\
\hline
\end{tabular}

nisone, salbutamol, ipratropium, and two way interactions between these factors. A p value less than 0.05 was considered significant. Only $p$ values less than 0.1 are mentioned in the text. All calculations were performed with the statistical software package SPSS/PC+, V3.1 (SPSS, Chicago, United States).

\section{Results}

Table 1 shows the clinical characteristics of the patients at randomisation. Two patients were excluded from the analysis because they developed an exacerbation: patient 9 dropped out during the first (prednisone) period and patient 10 during the second (budesonide) period. The analysis is based on the remaining eight patients. Order and carry over effects were not significant.

\section{EFFECTS OF BRONCHODILATORS}

All subjects received three doses of bronchodilator on each bronchodilator study day. The absolute increment in $\mathrm{FEV}_{1}$ from step 2 to step 3 was always $\leqslant 0 \cdot 10$ (mean 0.03 ) litre for ipratropium and always $\leqslant 0.15$ (mean 0.04 ) litre for salbutamol. Both bronchodilators individually and the combination caused significant changes in $\mathrm{FEV}_{1}$ and $\mathrm{PC}_{20}(\mathrm{p}<0.001$, for both variables).

Dose-response curves of $\mathrm{FEV}_{1}$ after the placebo period showed no substantial differences between the three bronchodilator curves (figure 1). Final $\mathrm{FEV}_{1}$ values (table 2) were significantly higher after the inhaled bronchodilators than after placebo ( $p=0.004$ for ipratropium, $p=0.008$ for salbutamol, and $\mathrm{p}=0.002$ for the combination). No significant differences existed between the two bronchodilators or between the combination of ipratropium and salbutamol and either drug alone. Individual responses varied within the group, though most subjects showed a somewhat larger response to salbutamol than to ipratropium (figure 2).

The effects of bronchodilators on histamine responsiveness after the placebo period were less uniform (table 2). $\mathbf{P C}_{20}$ values were significantly higher after salbutamol alone and the bronchodilator combination than after placebo, by 1.64 and 2.02 doubling concentrations ( $p=0.002$ and $p=0.003$, respectively). The difference between ipratropium and placebo $(0.83$ doubling concentrations) was not significant. The $\mathbf{P C}_{20}$ after salbutamol was significantly higher than that after ipratropium $(p=0.02)$. The effects of the combined salbutamol and ipratropium did not differ from that of salbutamol alone, and the difference from the effect of ipratropium alone (1.19 doubling concentrations) was not significant ( $p$

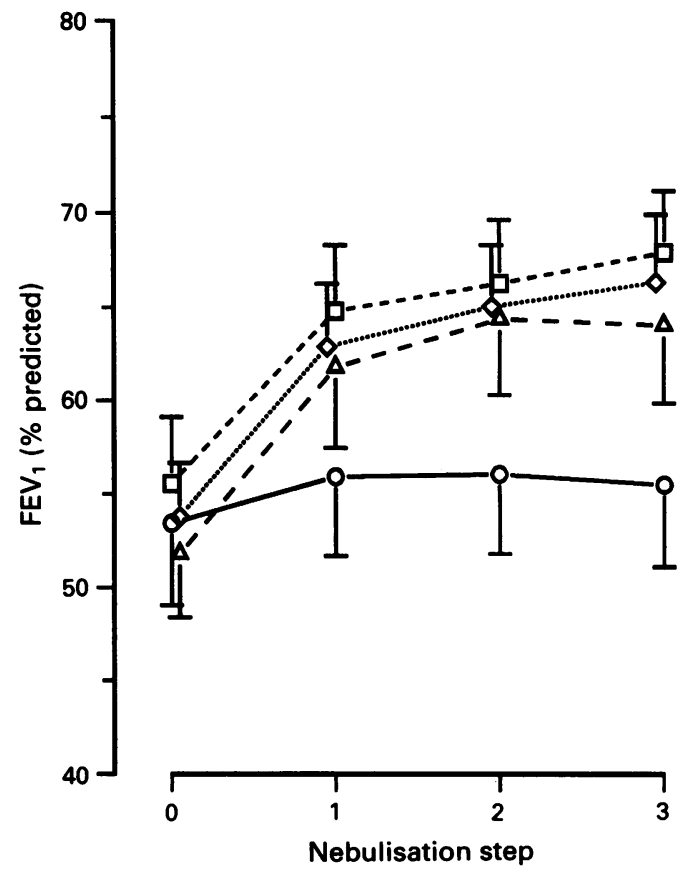

Figure 1 Effect of bronchodilators on FEV, after placebo treatment: placebo ( $O$ ), ipratropium $(\triangle)$, salbutamol $(\diamond)$, and combination of ipratropium and salbutamol ( $\square$ ). Differences between bronchodilators in terms of the final FEV, were not significant. 
Table 2 Effects of corticosteroids and bronchodilators on FEV, and $P C_{20}$ histamine

\begin{tabular}{|c|c|c|c|c|c|c|}
\hline \multirow[b]{2}{*}{ Treatment } & \multicolumn{6}{|c|}{ Bronchodilator: } \\
\hline & \multicolumn{2}{|l|}{ Placebo } & Ipratropium & Salbutamol & \multicolumn{2}{|c|}{ Combination } \\
\hline \multicolumn{7}{|c|}{ Mean (SE) $F E V_{1}$, (\% predicted) } \\
\hline $\begin{array}{l}\text { Placebo } \\
\text { Budesonide } \\
\text { Prednisone }\end{array}$ & $\begin{array}{l}55 \cdot 5 \\
55 \cdot 2 \\
58 \cdot 9\end{array}$ & $\begin{array}{l}(4 \cdot 4) \\
(4 \cdot 1) \\
(3 \cdot 2)\end{array}$ & $\begin{array}{ll}64 \cdot 0 & (4 \cdot 2) \\
64 \cdot 7 & (3 \cdot 8) \\
68 \cdot 8 & (3 \cdot 9)\end{array}$ & $\begin{array}{ll}67 \cdot 9 & (3 \cdot 3) \\
68 \cdot 5 & (3 \cdot 5) \\
70 \cdot 2 & (3 \cdot 7)\end{array}$ & $\begin{array}{l}66 \cdot 3 \\
66 \cdot 1 \\
70 \cdot 2\end{array}$ & $\begin{array}{l}(3.6) \\
(3.8) \\
(3.9)\end{array}$ \\
\hline \multicolumn{7}{|c|}{$\log _{2} P C_{20}(\mathrm{mg} / \mathrm{ml})$} \\
\hline $\begin{array}{l}\text { Mean (SE) } \\
\text { Geometric mean } \\
\text { Budesonide: }\end{array}$ & $\begin{array}{r}-0.87 \\
0.55\end{array}$ & $(0 \cdot 64)$ & $\begin{aligned}-0.04 & (0.55) \\
0.97 & \end{aligned}$ & $\begin{array}{ll}0.77 & (0.56) \\
1.71 & \end{array}$ & $\begin{array}{l}1 \cdot 15 \\
2 \cdot 22\end{array}$ & $(0.63)$ \\
\hline $\begin{array}{l}\text { Mean (SE) } \\
\text { Geometric mean } \\
\text { Prednisone: }\end{array}$ & $\begin{array}{r}-0.74 \\
0.60\end{array}$ & $(0.66)$ & $\begin{aligned}-0.01 & (0.45) \\
0.99 & \end{aligned}$ & $\begin{array}{ll}1 \cdot 63 & (0 \cdot 39) \\
3 \cdot 10 & \end{array}$ & $\begin{array}{l}1 \cdot 54 \\
2 \cdot 91\end{array}$ & $(0.56)$ \\
\hline $\begin{array}{l}\text { Mean (SE) } \\
\text { Geometric mean }\end{array}$ & $\begin{array}{r}-1.09 \\
0.47\end{array}$ & $(0 \cdot 82)$ & $\begin{array}{ll}0.30 & (0.52) \\
1.23 & \end{array}$ & $\begin{array}{ll}1.44 & (0.53) \\
2.71 & \end{array}$ & $\begin{array}{l}1 \cdot 80 \\
3 \cdot 48\end{array}$ & $(0 \cdot 64)$ \\
\hline
\end{tabular}

*Values measured after the final inhalation of bronchodilator.

$=0 \cdot 10)$. Most subjects showed a larger change in $\mathrm{PC}_{20}$ after salbutamol than after ipratropium (figure 2).

\section{EFFECTS OF CORTICOSTEROIDS}

Neither inhaled nor oral corticosteroids caused any significant change in $\mathrm{FEV}_{1}$ or $\mathrm{PC}_{20}$ (table 2). There was some variation within the group (figure 2).

\section{COMBINED EFFECTS OF CORTICOSTEROIDS AND} BRONCHODILATORS

The combined effects of corticosteroids and bronchodilators on $\mathrm{FEV}_{1}$ and $\mathrm{PC}_{20}$ were not significantly different from the sum of the separate effects for any combination. The shape and position of the $F E V_{1}$ dose-response curves for salbutamol after the placebo, budesonide, and prednisone periods did not differ (figure 3). The FEV 1 after the last dose of salbutamol did not differ significantly between prednisone and placebo $(p=0.07)$ or between budesonide and placebo or prednisone (table 2). The dose-response curves for ipratropium after placebo, budesonide, and prednisone are also shown in figure 3. Although mean $\mathrm{FEV}_{1}$ values were higher after prednisone, the final $\mathrm{FEV}_{1}$ values after ipratropium did not differ between the three periods.

$\mathrm{PC}_{20}$ values after salbutamol were higher following corticosteroid treatment, by 0.86 doubling concentrations after budesonide and by 0.67 doubling concentrations after prednisone, compared with the placebo treatment (table 2). The $\mathrm{PC}_{20}$ after ipratropium showed a small increase, of 0.03 doubling concentrations following budesonide and 0.34 doubling concentrations after prednisone, compared with placebo. None of these changes in $\mathrm{PC}_{20}$ was significant.

\section{Discussion}

This study was carried out to investigate the effects of short term treatment with corticosteroids on the airway response to bronchodilators. High doses of inhaled or oral corticosteroids did not modify the effects of salbutamol and ipratropium on $\mathrm{FEV}_{1}$ and $\mathrm{PC}_{20}$ in non-allergic subjects with chronic obstructive lung disease.

Conflicting results have been obtained in trials which attempted to estimate corticosteroid sensitivity in patients with chronic obstructive lung disease. ${ }^{4-91617} \mathrm{~A}$ rapid response to oral corticosteroids, occurring one to four weeks after starting treatment, has been seen in patients with atopy, as well as a good
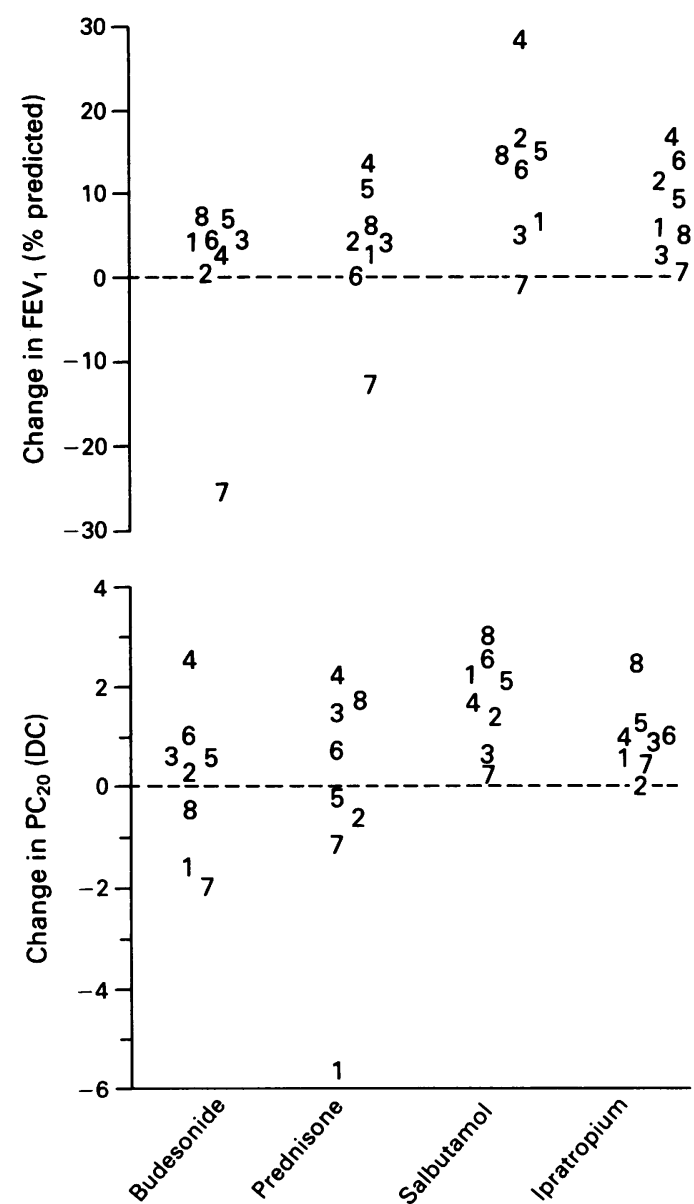

Figure 2 Individual changes in FEV, and $P C_{20}$ histamine after budesonide, prednisone, salbutamol, and ipratropium, compared with placebo (from multiple regression). 


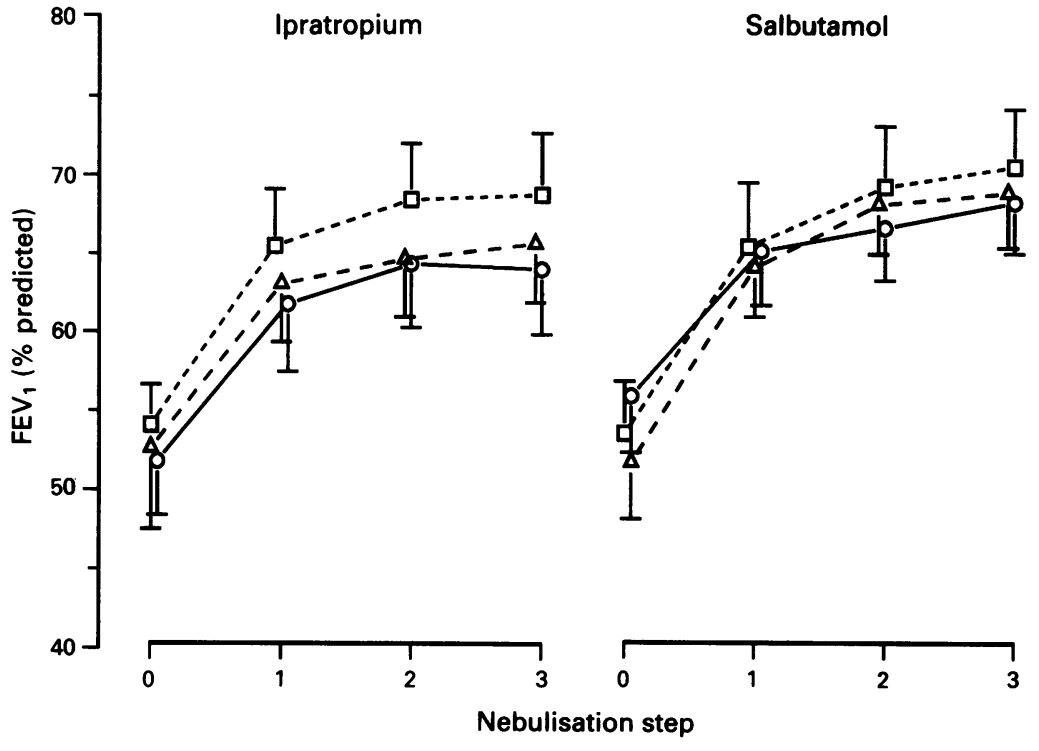

Figure 3 Effects of pretreatment with placebo $(O)$, budesonide $(\triangle)$, and prednisone ( 1 ) on ipratropium and salbutanol dose-response curves. No significant differences in

response to bronchodilators. ${ }^{4-6}$ We carefully excluded patients with asthma and atopy and found no effect with a short period of treatment with high doses of corticosteroids, though the responses varied within the group. The corticosteroid responses of subjects 1 and 7 after budesonide and prednisone were surprising as confounding factors such as pulmonary infections and seasonal influences were absent. Exclusion of these data changed mean values slightly but did not alter the outcome of statistical analyses.

Weir et al found that $\mathrm{FEV}_{1}$ continued to increase after 14 days of corticosteroid treatment in some subjects with chronic airflow limitation ${ }^{18}$ and raised questions about the use of a two week prednisone regimen. ${ }^{19}$ Such a regimen is commonly used, and we chose it for our study. Weir et al included patients with high IgE concentrations and eosinophil counts, which makes comparison with our non-allergic group difficult. ${ }^{18}$ Subgroups of patients with chronic obstructive lung disease may differ with regard to required dose and formulation of corticosteroid treatment and in response time. More research needs to be directed at distinguishing these subgroups to enable prediction of corticosteroid sensitivity.

Patients with chronic obstructive lung disease generally respond better, or at least equally well, to an anticholinergic drug than to a $\beta$ agonist in commonly used doses. ${ }^{20-23}$ Whether these doses are sufficient for a maximal effect is uncertain, especially as it has been suggested that responsiveness to $\beta$ agonists decreases with age. ${ }^{21}$ We assessed cumulative dose-response curves, which show a greater airway response than non-cumulative and single dose studies, ${ }^{24}$ and found a clear plateau with ipratropium; the plateau was less obvious with salbutamol. Airflow limitation in patients with chronic obstructive lung disease is determined by two components: a fixed part caused by damage of airway structure, and a reversible part, mainly caused by parasympathetic tone in airway smooth muscle (other factors such as allergic processes contribute little). Salbutamol and ipratropium produce similar bronchodilatation, which implies that they act equally strongly in counteracting this parasympathetic tone.

The mechanisms underlying the protection against constricting stimuli by bronchodilators are not completely understood. ${ }^{25} \beta$ Agonists provide better protection against histamine than anticholinergics in patients with asthma ${ }^{26-29}$ and chronic bronchitis, ${ }^{29}$ and the effect of $\beta$ agonists, but not of anticholinergics, is dose dependent. ${ }^{28}$ Bronchodilators may exert a protective effect by increasing airway diameter, since airway diameter is assumed to be a determining factor of responsiveness in patients with chronic obstructive lung disease. ${ }^{30}$ We found that salbutamol and ipratropium produced comparable values of $\mathrm{FEV}_{1}$, yet better protection by salbutamol was evident. This stronger functional antagonistic action of $\beta$ agonists is probably mainly due to effects on smooth muscle cells but may also be mediated by reducing the histamine induced swelling of the airway wall. Cholinergic mechanisms-for example, vagal reflex mechanisms-do not seem to play an important part in the histamine induced obstruction.

In our study the effects of the combination of salbutamol and ipratropium were similar to the effects of salbutamol alone. However, we gave high nebulised doses of bronchodilator. Commonly used doses may show additive effects ${ }^{32}$ and produce fewer side effects, and may therefore be useful in clinical practice.

We did not find significant modifying effects of corticosteroids on bronchodilator action, but only a small group of patients was studied for a relatively short time. Generalisation of the results to the whole population of patients with chronic obstructive lung disease is therefore not unjustified. Nevertheless, some of the trends we observed are interesting and need further study. The higher $\mathbf{P C}_{20}$ values after salbutamol following treatment with budesonide and prednisone, and the raised doseresponse curve for ipratropium after prednisone, both in the absence of corticosteroid effects on baseline values, were not significant but may be due to some synergistic effect. There is some evidence in the literature of an effect of corticosteroids on $\beta$ agonist response. Corticosteroids are capable of restoring $\beta$ responsiveness in previously non-responsive asthmatic patients ${ }^{10}$ and in normal subjects. ${ }^{12}$ A synergistic effect of corticosteroids and $\beta$ agonists in subjects without evidence of a diminished $\beta$ responsiveness could not be shown. ${ }^{33} 34$ Studies in vitro have shown an increase in concentrations of $\beta$ receptors after corticosteroid treatment. ${ }^{35}{ }^{36}$ Future research, especially on the long term effects of corticosteroids on bronchodilator action, is needed.

In conclusion, our study showed that cumulative doses of nebulised salbutamol and ipratropium result in similar bronchodilatation in non-allergic subjects with chronic obstructive lung disease. Salbutamol, however, gave better protection against histamine challenge and may be preferable for clinical purposes. 
Short term treatment with corticosteroids had no effects on airflow limitation and airway responsiveness and did not modify the bronchodilating and protective effects of bronchodilators.

We thank Astra, Boehringer Ingelheim, and Glaxo for supplying the drugs. This study was supported by grant No 8526 from Nederlands Astma Fonds.

1 Easton JG. Effect of an inhaled corticosteroid on methacholine airway reactivity. J Allergy Clin Immunol 1981; 67:388-90.

2 Ryan G, Latimer KM, Juniper EF, Roberts RS, Hargreave FE. Effect of beclomethasone dipropionate on bronchial responsiveness to histamine in controlled non-steroiddependent asthma. J Allergy Clin Immunol 1985;75:25-30.

3 Kraan J, Koëter GH, van der Mark ThW, Boorsma M, Kukler J, Sluiter HJ, et al. Dosage and time effects of inhaled budesonide on bronchial hyperreactivity. Am Rev Respir Dis 1988;137:44-8.

4 Harding SM, Freedman D. A comparison of oral and inhaled steroids in patients with chronic airways obstruction: features determining response. Thorax 1978;33:214-8.

5 Mendella LA, Manfreda J, Warren CPW, Anthonisen NR. Steroid response in stable chronic airflow obstruction. Ann Intern Med 1982;96:17-21.

6 Eliasson $\mathrm{O}$, Hoffman J, Trueb D, Frederick D, McCormick JR. Corticosteroids in COPD. A clinical trial and reassessment of the literature. Chest 1986;89:484-90.

7 Engel T, Heinig JH, Madsen O, Hansen M, Weeke ER. A trial of inhaled budesonide on airway responsiveness in smokers with chronic bronchitis. Eur Respir J 1989;2: 935-9.

8 Weir DC, Robertson AS, Gove RI, Sherwood Burge P. Corticosteroid trials in non-asthmatic chronic airflow obstruction: a comparison of oral prednisolone and inhaled beclomethasone dipropionate. Thorax 1990;45: 112-7.

9 Auffarth B, Postma DS, de Monchy JGR, van der Mark ThW, Boorsma M, Koëter GH. Effects of inhaled budesonide on spirometry, reversibility, airway hyperresponsiveness and cough threshold in smoking patients with chronic obstructive disease. (COPD). Thorax 1991;46:372-7.

10 Ellul-Micallef R, Fenech FF. Effects of intravenous prednisolone in asthmatics with diminished adrenergic responses. Lancet 1975;ii:1269-71.

11 Shenfield GM, Hodson ME, Clarke SW, Paterson JW. Interaction of corticosteroids and catecholamines in the treatment of asthma. Thorax 1975;30:430-5.

12 Holgate ST, Baldwin CJ, Tattersfield AE. $\beta$-Adrenergic agonist in normal human airways. Lancet 1977;ii:375-7.

13 Lightbody IM, Ingram CG, Legge JS, Johnston RM. Ipratropium bromide, salbutamol and prednisolone in bronchial asthma and chronic bronchitis. $\mathrm{Br} J$ Dis Chest 1978;72:181-6.

14 Quanjer PhM. Standardized lung function testing. Bull Eur Physiopathol Respir 1983;19 (suppl 5):1-93.

15 Cockcroft DW, Killian DN, Mellon JJA, Hargreave FE. Bronchial reactivity to inhaled histamine: a method and clinical survey. Clin Allergy 1977;7:235-43.

16 Shim C, Stover DE, Williams Jr MH. Response to corticosteroids in chronic bronchitis. J Allergy Clin Immunol 1978;62:363-7.

17 Wardman AG, Simpson FG, Knox AJ, Page RL, Cooke NJ. The use of high dose inhaled beclomethasone dipropion- ate as a means of assessing steroid responsiveness in obstructive airways disease. $\mathrm{Br} J$ Dis Chest 1988;82: 168-71.

18 Weir DC, Robertson AS, Gove RI, Sherwood Burge P. Time course of response to oral and inhaled corticosteroids in non-asthmatic chronic airflow obstruction. Thorax 1990;45:118-21.

19 Webb J, Clark TJH, Chilvers C. Time course of response to prednisolone in chronic airflow obstruction. Thorax 1981;36:18-21.

20 Petrie GR, Palmer KNV. Comparison of aerosol ipratropium bromide and salbutamol in chronic bronchitis and asthma. $B M J 1975 ; \mathrm{i}: 430-2$.

21 Ullah ML, Newman GB, Saunders K. Influence of age on response to ipratropium and salbutamol in asthma. Thorax 1981;36:523-9.

22 Jenkins CR, Chow CM, Fisher BL, Marlin GE. Comparison of ipratropium bromide and salbutamol by aerosolized solution. Aust NZ J Med 1981;11:513-6.

23 Easton P, Jadue C, Dhingra S, Anthonisen NR. A comparison of the bronchodilating effects of a beta-2 adrenergic agent (albuterol) and an anticholinergic agent (ipratropium bromide) given by aerosol alone or in (ipratropium bromide) given by aerosol

24 Britton J, Tattersfield A. Comparison of cumulative and non-cumulative techniques to measure dose-response curves for beta-agonists in patients with asthma. Thorax 1984;39:597-9.

25 Tattersfield AE. Effect of beta-agonists and anticholinergic drugs on bronchial hyperreactivity. Am Rev Respir Dis 1987;136 (suppl 4):64-8.

26 Cockcroft DW, Kilian DW, Mellon JJA, Hargreave FE. Protective effect of drugs on histamine-induced asthma. Thorax 1977;32:429-37.

27 Bandouvakis J, Cartier A, Roberts R, Ryan G, Hargreave FE. The effect of ipratropium and fenoterol on methacholine- and histamine-induced bronchoconstriction. $\mathrm{Br}$ J Dis Chest 1981;75:295-305.

28 Britton J, Hanley SP, Garrett HV, Hadfield JW, Tattersfield AE. Dose-related effects of salbutamol and ipratropium bromide on airway calibre and reactivity in subjects with asthma. Thorax 1988;43:300-5.

29 Higgins BJ, Powell RM, Cooper S, Tattersfield AE. Effect of salbutamol and ipratropium bromide on airway calibre and bronchial reactivity in asthma and chronic bronchitis. and bronchial reactivity in as

30 Ramsdale EH, Morris MM, Roberts RR, Hargreave FE. Bronchial responsiveness to methacholine in chronic bronchitis: relationship to airflow obstruction and cold air responsiveness. Thorax 1984;39:912-8.

31 Yan K, Salome CM, Woolcock AJ. Prevalence and nature of bronchial hyperresponsiveness in subjects with chronic obstructive pulmonary disease. Am Rev Respir Dis 1985; 132:25-9.

32 Grandordy BM, Thomas V, de Lauture D, Marsac J. Cumulative dose-response curves for assessing combined effects of salbutamol and ipratropium bromide in chronic asthma. Eur Respir J 1988;1:531-5.

33 Molema J, Van Herwaarden CLA, Lammers JWJ, Folgering HThM. Effects of different doses of inhaled beclomethasone dipropionate $(500,1000,2000 \mathrm{mcg} /$ day $)$ on $\beta_{2}$-receptor function in the airways and adrenal responsiveness in bronchial asthma. Eur J Clin Pharmacol 1988;34:577-83.

34 Curzon PGD, Martin MA, Cooke NJ, Muers MF. Effect of oral prednisolone on response to salbutamol and ipratropium bromide aerosols in patients with chronic airflow obstruction. Thorax 1983;38:601-4.

35 Fraser CM, Venter JC. The synthesis of beta-adrenergic receptors in cultured human lung cells: induction by glucocorticoids. Biochem Biophys Res Commun 1980;94: 390-7.

36 Hui KP, Conolly ME, Tashkin DP. Reversal of human lymphocyte beta-adrenergic receptor desensitization by glucocorticoids. Clin Pharmacol Ther 1982;32:566-71. 